\title{
A Kantian Case for Animal Rights
}

\section{Citation}

Korsgaard, Christine M. "A Kantian Case for Animal Rights." 2012. In Animal Law - Tier and Rect: Developments and Perspectives in the 21st Century, ed. Margot Michael, Daniela Kühne, and Julia Hänni, 3-27. Zurich: Dike Verlag.

\section{Published Version}

10.1093/acprof:oso/9780199396078.003.0010

\section{Permanent link}

http://nrs.harvard.edu/urn-3:HUL.InstRepos:34903186

\section{Terms of Use}

This article was downloaded from Harvard University's DASH repository, and is made available under the terms and conditions applicable to Open Access Policy Articles, as set forth at http:// nrs.harvard.edu/urn-3:HUL.InstRepos:dash.current.terms-of-use\#OAP

\section{Share Your Story}

The Harvard community has made this article openly available.

Please share how this access benefits you. Submit a story.

Accessibility 


\section{A Kantian Case for Animal Rights}

Christine M. Korsgaard

Table of Contents

I. Introduction

II. Why We Must Regard Animals as Ends in Themselves

III. Why We Have Moral Duties to Animals

IV. Why Animals Should Have Legal Rights

V. Conclusion

\section{Introduction}

Kantian moral philosophy is usually considered inimical both to the moral claims and to the legal rights of non-human animals. Kant himself asserts baldly that animals are "mere means" and "instruments" and as such may be used for human purposes. In the argument leading up to the second formulation of the categorical imperative, the Formula of Humanity as an end in itself, Kant says:

Beings the existence of which rests not on our will but on nature, if they are beings without reason, have only a relative worth, as means, and are therefore called things, whereas rational beings are called persons because their nature already marks them out as an end in itself,

\footnotetext{
* Arthur Kingsley Porter Professor of Philosophy, Department of Philosophy, Harvard University.
} 
In his essay "Conjectures on the Beginnings of Human History," a speculative account of the origin of reason in human beings, Kant explicitly links the moment when human beings first realized that we must treat one another as ends in ourselves with the moment when we realized that we do not have to treat the other animals that way. He says:

When [the human being] first said to the sheep, "the pelt which you wear was given to you by nature not for your own use, but for mine" and took it from the sheep to wear it himself, he became aware of a prerogative which, by his nature, he enjoyed over all the animals; and he now no longer regarded them as fellow creatures, but as means and instruments to be used at will for the attainment of whatever ends he pleased. (CBHH 8:114)

\footnotetext{
${ }^{1}$ Kant's works are cited in the traditional way, by the volume and page number of the standard German edition, Kants Gesammelte Schriften (edited by the Royal Prussian (later German) Academy of Sciences (Berlin: George Reimer, later Walter de Gruyter \& Co., 1900--)), which are found in the margins of most translations. The abbreviations I have used are as follows; for the translations used, please see the bibliography.

C3 $=$ Critique of Judgment $\mathrm{C} 2=$ Critique of Practical Reason $\mathrm{CBHH}=$ "Conjectures on the Beginnings of Human History"

${ }^{2}$ I have changed Nisbet's rendering of the German 'Pelz' from 'fleece' to 'pelt' although the German can be rendered either way, because I think that the rendering "fleece" softens Kant's harsh point.
} 
In his account of legal rights, Kant introduces a further difficulty for the cause of animal rights. For Kant, the point of legal rights is not, as many philosophers have supposed, to protect our more important interests. Rather, it is to define and uphold a maximal domain of individual freedom for each citizen, within which the citizen can act as seems just and good to him. In John Rawls's language, it is to create a domain in which each person can pursue his own "conception of the good." ${ }^{3}$ Kant believed that each of us has an innate right to freedom, which he defined as "independence from being constrained by another's choice" (MM 6:237). He argued that without the institution of enforceable legal rights, our relationships with each other must be characterized by the unilateral domination of some individuals over others. The problem is not, or not merely, that the strong are likely to tyrannize over the weak. Even if the strong were scrupulous about not interfering with the actions or the possessions of the weak, still, without rights, the weak would be able to act on their own judgment and retain their own possessions only on the sufferance of the strong (MM 6:312). Since her innate right to freedom is violated when one person is dependent on some other person's good will, Kant thinks it is a duty, and not just a convenience, for human beings to live in a political state in which every person's rights are enforced and upheld (MM 6:307-8). ${ }^{4}$ No matter how well-intentioned we

\footnotetext{
${ }^{3}$ RAWLS, Theory of Justice; first used on xii.

${ }^{4}$ The contrast here is with Locke and Hobbes, who supposed that we leave the "state of nature" as a remedy for its "inconveniences" (the word is Locke's) and therefore from motives of prudence rather than because it is morally required. See LOCKE, Second Treatise and HOBBES, Leviathan.
} 
are, we can be rightly related to each other only if we live in a political state with a legal system that guarantees the rights of everyone.

But non-rational animals apparently do not have the kind of freedom that rights, on this account, are intended to protect. It is because human beings are rational beings that we are able to choose our own way of life. Rationality, for Kant, is not the same thing as intelligence. It is a normative capacity, grounded in what Kant took to be the unique human ability to reflect on the reasons for our beliefs and actions, and decide whether they are good reasons or bad ones. As rational beings, we reflect about what counts as a good life, decide the question for ourselves, and live accordingly. In the liberal tradition, with its strong emphasis on toleration and its antagonism to paternalism, this kind of autonomy has often been regarded as the basis of at least some of our rights. We have the basic rights of personal liberty, liberty of conscience, and the freedom of speech and association, because each of us has a general right to determine for ourselves what counts as a worthwhile life, and to live that life, so long as the way we act is consistent with upholding the same right for everyone else.

But Kant extends this account to all of our rights. He thinks that we must have property rights, for example, because if we did not, no one could use natural objects - a piece of land to grow crops on, for example - to pursue his own projects without being dependent on the willingness of others not to interfere with that use. Our right to property is therefore not grounded directly in our interests, but rather is seen as an extension of our freedom of action. Of course Kant thought that one of 
the things in which we could claim property is the other animals. Their legal status as property is the direct correlate of their moral status as mere means.

Grounding all of our rights in freedom is important to Kant, because on Kant's account, rights, by their very nature, are coercively enforceable. It is the essence of having a right that you may legitimately use force to protect that to which you have the right, or the state may do so on your behalf. That is how rights secure our freedom against the domination of others. Kant believed that the protection of freedom is the only thing that justifies the use of coercion, because the protection of freedom is the use of coercion against coercion itself. According to Kant, people do not get to push each other around in the name of what one or another of us, or the majority of us, or for that matter, even all of us, considers to be good. The only thing that justifies us in preventing someone from acting as she chooses is that her action is a hindrance to someone else's freedom.

But the other animals are not autonomous and do not choose their own way of life. This seems to imply that in Kant's legal philosophy, questions about the rights of non-rational animals cannot even come up. And of course, those who champion rights for animals are not usually interested in securing their freedom of action, but rather in securing them protection from harm. This seems to suggest that Kant's philosophy is not the place to look for a philosophical foundation for animal rights.

Nevertheless, in this paper I will argue that a case for both the moral claims and the legal rights of non-human animals can be made on the basis of Kant's own 
moral and political arguments. Kant's views about the human place in the world his resistance to the pretensions that human beings have metaphysical knowledge of the way the world is in itself, and the arguments he uses to show that we can construct an objective moral system without such knowledge - require us to acknowledge our fellowship with the other animals.

\section{Why We Must Regard Animals as Ends in Themselves}

In the argument leading to the Formula of Humanity, as I mentioned earlier, Kant claims that the nature of rational beings or "persons" "marks us out" as ends in ourselves. As some people read this argument, Kant is simply making a metaphysical claim about a certain form of value. Rationality or autonomy is a property that confers a kind of intrinsic value or dignity on the beings who have it, and therefore they are to be respected in certain ways. Lacking this property, the other animals lack this dignity or value.

There are several problems with understanding Kant's argument this way. One is that it does nothing to explain the particular kind of value that rational beings are supposed to have. "Value" is not a univocal notion - different things are valued in different ways. The kind of value that Kant thinks attaches to persons is one in response to which we respect their choices, both in the sense that we leave people free to determine their own actions, and in the sense that we regard their chosen ends as things that are good and so worthy of pursuit. This is made clear by the nature of the duties that Kant thinks follow from the injunction to respect persons as ends in 
themselves (G 4:429-31). We are obligated not to usurp other people's control over their own actions by forcing or tricking them into doing what we want or think would be best - that is, we are not allowed to use other people as mere means to our ends. We also have a duty to promote the ends of others. A person could certainly have some kinds of value - even some kinds of value as an end - without it following that his choices ought to be respected. A prince, or someone held by some religious tradition to be the embodiment of their god, might be valued the way a precious object is valued - preserved and protected and cherished - without ever being allowed to do anything that he chooses.

But the more important problem is that the proposed claim about the intrinsic value of rational beings is exactly the sort of metaphysical claim whose pretensions Kant's philosophy is designed to debunk. Kant does not believe that human beings have the kind of direct rational insight into the nature of things that might tell us that certain entities or objects are, as a matter of metaphysical fact, intrinsically valuable. Speaking a bit roughly, Kant thinks that claims that go beyond the realm of empirical or scientific knowledge must be established as necessary presuppositions of rational activity - that is, as presuppositions of thinking in general, or of constructing a theoretical understanding of the world, or of making rational choices. His philosophical strategy is to identify the presuppositions of rational activity and then to try to validate those presuppositions through what he called "critique." 5

\footnotetext{
${ }^{5}$ This rough description of Kant's method skates over a great many complexities and controversies in Kant interpretation. What I am calling "presuppositions" are of various kinds - constitutive principles, regulative principles, and postulates, for instance; and the arguments Kant gives to validate them are also of various kinds - the special kind of argument he calls "deduction," for one; in the case
} 
In his argument for the Formula of Humanity, Kant aspires to show us that the value of people as ends in themselves is a presupposition of rational choice. The argument, as I understand it, it goes like this. ${ }^{6}$ Because we are rational, we cannot decide to pursue an end unless we take it to be good. This requirement is essentially built in to the nature of the kind of self-consciousness that grounds rational choice. A rational being is one who is conscious of the grounds on which she is tempted to believe something or to do something - the purported reasons that move her to adopt a belief or an intention. Because we are conscious of the grounds of our beliefs and actions, we cannot either hold a belief or perform an action without endorsing its grounds as adequate to justify it. ${ }^{7}$ To say that the pursuit of an end is justified is the same as to say that the end is good (C2 5:60). Importantly, Kant takes the judgment that the end is good to imply that there is reason for any rational being to promote it. As he says in the Critique of Practical Reason:

of the argument for the moral law in the Second Critique, the establishment of a "credential" (C2 5:48) for another, and others as well. In addition, there is philosophical controversy over the nature of the specific validation Kant ultimately proposed for the moral law, and Kant himself changed his mind about this over the course of his career. Despite these complications, I think that the rough description of Kant's method generally fits all these cases.

In this paper my focus is on the presuppositions themselves, not on their validation. I will argue that in certain ways Kant misidentified the presuppositions of practically rational activity. That leaves it open, I suppose, that the revised presuppositions cannot be validated. Because of the great obscurity of Kant's methods of validation, especially in moral philosophy, it is a little difficult for me to address this worry in general terms, but I do not believe it is a problem. I think Kant was right in concluding that the presuppositions of rational action do not need a deduction in the same sense that the presuppositions of theoretical understanding do.

${ }^{6}$ I first presented a version of this interpretation of Kant's argument in KORSGAARD, Formula of Humanity.

${ }^{7}$ This is not to say that weakness of the will and moral weakness are impossible, of course, but it implies that they must be explained in terms of self-deception. 
What we are to call good must be an object of the faculty of desire in the judgment of every reasonable human being, and evil an object of aversion in the eyes of everyone [...] (C2 5:61) $)^{8}$

What he means is not that everyone must care about the same things that I do, but rather, that if my caring about an end gives me a genuine reason for trying to make sure that I achieve it, then everyone else has a reason, although of course not necessarily an overriding one, to try to make sure that I achieve it as well.

Consequently, Kant envisions the act of making a choice as the adoption of a certain 'maxim' or principle as a universal law, a law that governs both my own conduct and that of others. My choosing something is making a law in the sense that it involves conferring a kind of objective - or more properly speaking intersubjective - value on some state of affairs, a value to which every rational being must then be responsive. It is important to Kant's own understanding of the implications of this argument that it is only rational choices that have this normative character. Only rational choices are made on the basis of an assessment of the grounds or reasons for them, and so only rational choices represent decisions about what should be done.

\footnotetext{
${ }^{8}$ Someone might of course challenge Kant's claim that the adequacy of one's reason implies that one's end is an end for everyone. Kant's assumption is that reasons are what I have elsewhere called "public," or what are sometimes called "agent-neutral," reasons - reasons whose normative force extends to all rational beings. I have defended this assumption in various places, including KORSGAARD, Sources of Normativity, Lecture 4, and KORSGAARD, Self-Constitution, Chapter 9. It would take me too far afield to discuss this complex issue here. I assume that the primary audience for the argument of this paper is people who are prepared to grant that human beings or rational beings have legitimate moral and legal claims on each other, and who therefore are prepared to grant that in some sense we are laws to each other, even if they are unsure whether the other animals also have such claims on us.
} 
The other animals do not make choices in the same sense that rational beings do, and such choices as they do make do not have the character of laws.

Most of the ends we choose, however, are simply the objects of our inclinations, and the objects of our inclinations are not, considered just as such, intrinsically valuable. As Kant puts it:

The ends that a rational being proposes at his discretion as effects of his actions (material ends) are all only relative; for only their mere relation to a specially constituted faculty of desire gives them their worth $[\ldots](\mathrm{G} 4: 428)$

The objects of your own inclinations are only - or rather at most - good for you, that is, good relative to the "special constitution" of your faculty of desire." As Kant thinks of it, they are, usually, things that you like and that you think would make you happy. Now it does not generally follow from the fact that something is good for someone in particular that it is good absolutely, and that anyone has reason to promote it. As I have already mentioned, Kant supposes that a rational being pursues an end only if she thinks it is good absolutely, so he thinks we do not pursue the objects of our inclinations merely because we think those ends are good for us. Yet we do pursue the objects of our inclinations, and we often expect others to help us in small ways, or at least not to interfere without some important reason for doing

\footnotetext{
${ }^{9}$ I say, "or at most" because of course we might desire things that are bad for us, that are inconsistent with our happiness, and that are not rational to choose on that ground.
} 
so. That suggests that we take it to be absolutely good that we should act as we choose and get the things that are good for us. Why do we do that?

That is the question from which the argument for the Formula of Humanity takes off, and Kant's answer is that we do it because we take ourselves to be ends in ourselves. He says:

[...] rational nature exists as an end in itself. The human being necessarily represents his own existence this way; so far it is thus a subjective principle of human actions. (G 4:429)

We "represent" ourselves as ends in ourselves insofar as we take what is good for us to be good absolutely. It is as if whenever you make a choice, you said, "I take the things that are important to me to be important, period, important absolutely, because I take myself to be important." So in pursuing what you think is good for you as if it were good absolutely, you show that you regard yourself as an end in itself, or perhaps to put it in a better way, you claim that standing. Kant then continues:

But every other rational being also represents his existence in this way consequent on just the same rational ground that also holds for me; thus it is at the same time an objective principle [...] (G 4:429)

Kant tells us that at this point in the argument that is just a "postulate," which he will prove later in the book, in its final section. In the final section of the book, Kant sets out the grounds that he thinks validate our conception of ourselves, considered as rational beings, as members of what he calls a Kingdom of Ends, a community in 
which all rational beings as ends in themselves together make laws for themselves and for one another whenever they make choices.

So whenever you make a rational choice, then, you presuppose that you, and by implication, every other rational being, has a kind of normative standing, the standing of a legislator in the Kingdom of Ends, whose choices are laws to all rational beings. It is in this sense that Kant thinks your rational nature "marks you out" as an end in itself. Of course, in the moral realm, your right to confer objective value on your ends and actions is limited by everyone else's right to confer objective value on his ends and actions in the same way. (This is analogous to the way that, in the political realm, your freedom is limited by the like freedom of everyone else.) So only if your principle or maxim is morally permissible does it really count as a law. In Kant's own language, your maxim must conform to the categorical imperative: you must be able to will it as a universal law. Kant takes that to means that ultimately it is a rational being's capacity for moral choice that "marks him out" as an end in himself. As Kant says:

Now morality is the condition under which alone a rational being can be an end in itself, since only through this is it possible to be a lawmaking member in the kingdom of ends. ( $G$ 4:435)

While recounting these arguments, I have switched back and forth between talking about our standing as lawmakers, and talking about our standing as beings whose ends and actions should be regarded as good, and so as normative for everyone. That reflects the fact that there are two slightly different senses of "end in 
itself" at work in Kant's argument, which we might think of as an active and a passive sense. I must regard you as an end in itself in the active sense if I regard you as capable of legislating for me, and so as placing me under an obligation to respect your choices or to help you to pursue your ends. I must regard you as an end in itself in the passive sense if I am obligated to treat your ends, or at least the things that are good for you, as good absolutely. Kant evidently thought that these two senses come to the same thing. For in his most explicit statement about why we have duties only to rational beings, Kant says:

As far as reason alone can judge, a human being has duties only to human beings (himself and others), since his duty to any subject is moral constraint by that subject's will. (MM 6:442) ${ }^{10}$

But that does not obviously follow. The idea that rational choice involves a presupposition that we are ends in ourselves is not the same as the idea that rational choice involves a presupposition that rational beings are ends in themselves, for we are not merely rational beings. The content of the presupposition is not automatically

\footnotetext{
${ }^{10}$ The point of the caveat in the first clause is to leave room for duties owed to God, and grounded in faith. Since Kant thinks we cannot prove there is a God who is a rational being with a will, or have theoretical knowledge what God's will is, we cannot owe duties to God "as far as reason alone can judge." This is not inconsistent with Kant's occasional suggestion that we should view God as the sovereign of the Kingdom of Ends ( $G$ 4:433, 4:439). There is a sense in which Kant himself thinks faith itself is grounded in reason, but it is not the usual sense: Kant does not think that there are successful theoretical arguments for the existence of God and the possibility of a future life. Rather, he thinks our moral commitments require us to hope that a fully moral state of the world can be achieved, and the "postulates" of God and Immortality, the objects of "practical faith," give us a picture of the conditions under which a morally perfect world could be achieved. Sadly, Kant did not envision that morally perfect world as including eternal happiness for the other animals. Rather, he tells that without such faith, all that even the best person can expect is "deprivation, disease, and untimely death, just like all the other animals of the earth." (C3 5:452) For further reflections on this aspect of Kant's moral philosophy, see KORSGAARD, Just Like All the Other Animals.
} 
given by the fact that it is rational beings who make it. Do we presuppose our value only insofar as we are beings who are capable of willing our principles as laws? Or do presuppose our value as beings for whom things can be good or bad? In fact, Kant's argument actually shows that we presuppose our value as beings for whom things can be good or bad - as we might put it for short, as beings who have interests. Let me explain why.

Suppose I choose to pursue some ordinary object of inclination, something that I want. According to Kant's argument, this choice presupposes an attitude I have towards myself, a value that I set on myself, or a standing that I claim. Is it my value as an autonomous being capable of making laws for myself as well as other people? Or is it my value as a being for whom things can be good or bad?

If it is the value that I set on myself as an autonomous being, then when I make a choice I should be motivated by respect for my own autonomy, my capacity to make laws. The natural way to understand the idea that I respect my own autonomy is to suppose that I conform to a law simply because I myself have made it. Kant certainly thinks that whenever I make a choice I make a kind of law for myself, as well as for other people, and the idea is not without content: it is the essential difference between choosing something and merely wanting it. Wanting something, which is just a passive state, does not include a commitment to continuing to want it, but willing something, which is an active state, does include a commitment to continuing to will it, everything else equal. For example, if I choose (or will, in Kant's language) to grow vegetables in my garden, knowing that this will 
require me to weed it on a regular basis, then I commit myself to weeding my garden at certain intervals in the future even should it happen that I do not feel like doing so. This is not to say that I decide that I will weed my garden no matter what - though the heavens fall, as it were. But it is to say that when I take something as the object of my will or choice, it follows that any good reason I have for abandoning this object must come from other laws that I have made or other commitments that I have undertaken, and not merely from a change in my desires. Having willed to grow vegetables in my garden, I can decide not to weed it if I need to rush to the bedside of an ailing friend, for instance. But I have not really decided, or willed, to grow vegetables in my garden if I leave it open that I will not weed my garden if I just do not happen to feel like it. For if all that I have decided when I decide I will keep my garden weeded is that I will weed it if I happen to feel like it, then I have not actually decided anything at all. ${ }^{11}$ So when I choose to grow vegetables as my end, I bind my future self to a project of regular weeding by a law that is not conditional on my future self's desires. In that sense, I have legislated a categorical imperative for myself. But my future self in turn also binds me, for it is essential that if she is going to do the necessary weeding, I now buy some pads to protect her knees, and the tools for her to weed with - and I must also do that whether I feel like it or not. In this simple sense, when I make a choice, I impose obligations on myself - I create reasons for myself. When I act on those reasons, you can say that I am respecting my own autonomy, by obeying the law that I myself have made.

\footnotetext{
${ }^{11}$ See KORSGAARD, Self-Constitution, $§ 4.5$ for a fuller version of this argument.
} 
When someone else respects my choice, he is also governed in this way by respect for my autonomy: he takes my choice to be law. But my own original decision to choose or will some desired end is not motivated by respect for my own autonomy in that sense. I cannot respect my own choice or do what is necessary to carry it out until after I have made that choice. So the sense in which I "represent myself" as an end in itself when I make the original choice is not captured by the idea that I respect my own autonomy, in the sense of taking my choice to be a law. When I make the original choice, I have no other reason for taking my end to be absolutely good, than that it is good for me. This suggests that the pertinent fact about me is simply that I am the sort of being for whom things can be good or bad, a being with interests.

Of course, someone might insist that I respect my own autonomy in a different sense: not in the sense that I treat a choice of my own as a law, but in the sense that I presuppose that what is good for autonomous rational beings, and only for autonomous rational beings, should be treated as good absolutely. But that conclusion is not driven by the argument: there is no reason to think that because it is only autonomous rational beings who must make the normative presupposition, the normative presupposition is only about autonomous rational beings. Notice, too, that many of the things that I take to be good for me are not good for me merely insofar as I am an autonomous rational being. Food, sex, comfort, freedom from pain and fear, are all things that are good for me insofar as I am an animate being. So it is more natural to think that the presupposition behind rational choice is that the 
things that are good for beings for whom things can be good or bad are to be treated as good or bad absolutely. But of course things can be good or bad, in the relevant way, for any sensate being, that is, for any being who can like and dislike things, be happy or suffer. ${ }^{12}$ That suggests that the presupposition behind rational choice is that animals, considered as beings for whom things can be good or bad - as beings with interests - are ends in themselves.

We might put the point this way. As rational beings, we need to justify our actions, to think there are reasons for them. That requires us to suppose that some ends are worth pursuing, are absolutely good. Without metaphysical insight into a realm of intrinsic values, all we have to go on is that some things are certainly good or bad for us. That then is the starting point from which we build up our system of values - we take those things to be good or bad absolutely - and in doing that we are taking ourselves to be ends in ourselves. But we are not the only beings for whom

\footnotetext{
${ }^{12}$ There is a sense in which things can be good or bad for any functionally organized being - namely, things can help or hinder its functioning. "Riding the brakes is bad for your car," we say in that sense. The car, however, is made for a human purpose, and the way in which things can be good or bad for it is derivative from that purpose: ultimately, what happens to the car is good or bad for people, not really for the car. Things can also be good or bad for plants, and this kind of goodness and badness is not derivative from human purposes ("The weeds are really flourishing in my garden; all this rain is good for them."). Rather, it is good for the plant considered as a living organism, functioning so as to survive and reproduce. The way in which things are good or bad for people and animals includes this, but adds a new dimension, for an animal has a point of view on which the things that are good or bad for it have an impact - they are also good or bad from the animal's point of view. In saying this, I am not endorsing the hedonistic conclusion that only experiences themselves can be good or bad, insofar as they are pleasant or painful. I am only suggesting that there is a sense of "good for" in which goodfor and bad-for are relative to the evaluative attitudes of the being for whom things are good or bad. By "evaluative attitudes" I mean desires, pains, pleasures, fears, loves, hates, ambitions, projects, and principles, and so on, some of which are experienced by every sensate being. This is the sense of "good for" that I take to be relevant to the argument. For further reflections see KORSGAARD, Origin of the Good.
} 
things can be good or bad; the other animals are no different from us in that respect.

So we should regard all animals as ends in themselves. ${ }^{13}$

\section{Why We Have Moral Duties to Animals}

But there is another way to understand Kant's argument against the moral claims of animals. In a passage I quoted earlier, Kant says:

As far as reason alone can judge, a human being has duties only to human beings (himself and others), since his duty to any subject is moral constraint by that subject's will. (MM 6:442)

One might place the emphasis here on the idea of owing a duty to someone, and take Kant to be claiming that it is impossible for us to owe a duty to an animal. It is, after all, notorious that Kant claimed that although we do have duties to treat animals humanely, we do not owe those duties to the animals, but rather to ourselves (MM 6:442; LE 27:459). ${ }^{14}$ This claim goes right to the heart of the issue about legal rights for animals, since the duty of respecting a legal right is something that is supposed to

\footnotetext{
${ }^{13}$ The main argument of this section was first advanced in KORSGAARD, Fellow Creatures.

${ }^{14}$ In fact Kant's views were rather advanced for his day. Kant thought animals should not be hurt or killed unnecessarily, and certainly not for sport (LE 27:460). If they must be killed, it should be quickly and without pain (MM 6:443). We should never perform painful experiments on them for merely speculative purposes, or if there is any other way to achieve the purpose of the experiment (MM 6:443). We should not require harder work of them than we would require of ourselves (MM 6:443). When they do work for us we should we treat them as members of the household (MM 6:443), and when they no longer can work for us, they are entitled to a comfortable retirement at our expense (LE 27:459). Non-human animals, according to Kant, are the proper objects of love, gratitude, and compassion, and failing to treat animals in accordance with these attitudes is "demeaning to ourselves" (MM 6:443; LE 27:710).
} 
be owed to the right holder. If we cannot owe duties to animals, then it seems that they cannot have rights.

In the passage I just quoted, Kant claims that to owe something to someone is to be constrained by his will. To see what this means, consider, first, what happens when you make a promise, and so incur an obligation. As Kant understood promises, what happens when you make a promise is that you transfer the right to make a certain decision, which is naturally your own right, to someone else, in rather the same way you might transfer a piece of property to someone else. If I promise to meet you for lunch at the cafeteria tomorrow, I transfer my right to decide whether to go to you, and I now no longer have the right to decide that I will not go unless you absolve me from my promise. So my decision now belongs to you - it is a matter for your will to determine, not for mine. So you are in a position to constrain me to go to the cafeteria by your will. You can obligate me.

There is another way to understand this same transaction, which is again in terms of the making of a law. As we will see later, Kant envisions the original acquisition of a piece of property as the making of a kind of law that binds everyone. For example, when I claim a piece of land as my own, I in effect say: no one may use this land without my permission, everyone is bound by my will about how this land may be used. But Kant thinks that I cannot make laws for everyone else unilaterally, since other people are free and not bound by my will. So if I am able to make laws of this kind, to claim things for my own, it can only be by speaking in the name of what Rousseau called the General Will, that is, in the name of the laws we 
will together. ${ }^{15}$ So when I make a promise, and so transfer my right to make a decision to you, we can understand that as our making a law together: when I promise to meet you and you accept my promise, we make a law together that my decision whether to meet you should belong to you and not to me. If our promises are mutual - if we promise to meet each other for lunch tomorrow - we both will the law that both of us should show up at the cafeteria tomorrow, and now neither of us can rescind the plan unilaterally. If I want to do something else, I have to get your permission, and if you want to do something else, you have to get mine. Having joined our wills under common law, we can only change things by making a new law together.

This gives us a way to understand those rights that are not incurred by particular actions, like the standing right not to be used as a mere means to someone else's ends. As we have seen, Kant supposes that all of us will that rational beings should be treated as ends in themselves, since (he thinks) the presupposition that rational beings should be treated as ends is built into every act of rational choice. So this is a law that, insofar as we are rational beings, we will together. The fact that we will it together is what makes it possible for us to make claims on each other in its name: we can bind one another through our wills. But the other animals neither participate in making moral laws, nor are they under the authority of those laws. They therefore cannot obligate us in the name of moral laws, and so cannot make moral claims on us.

\footnotetext{
${ }^{15}$ RousSEAU, Social Contract. The term is first used in chapter VII, p. 26.
} 
So understood, Kant's argument is a version of what I call a "reciprocity argument." A reciprocity argument holds that human beings have either no duties at all, or no duties of justice (i.e., duties associated with rights), to the other animals, because such duties depend on relations of reciprocity. There are various versions of the argument. One is a crude picture of morality as a kind of social contract or bargain, whose content is something like: "I will act with a certain kind of restraint towards you, if you will act with a similar restraint towards me." This version prompts the obvious question how we are to explain our duty to keep the social contract itself. That duty cannot be grounded in the contract.

Another version is associated with David Hume's argument that the requirements of justice only hold in certain conditions, conditions which John Rawls later called "the circumstances of justice." ${ }^{16}$ Hume makes the argument in order to prove that the requirements of justice are grounded in considerations of utility. We expect people to conform to the requirements of justice only under certain conditions, he argues, and those conditions are exactly the ones in which conforming to the requirements of justice is useful to all concerned. Therefore it must be the utility that grounds the requirements. One of these conditions is an approximate equality of power between the parties to the social contract, which renders it in the interest of all parties to make and maintain the contract. On these grounds, Hume argues that we do not have duties of justice to the other animals. He says:

\footnotetext{
${ }^{16}$ RAWLS, Theory of Justice. $§ 22$.
} 
Were there a species of creatures intermingled with men, which, though rational, were possessed of such inferior strength, both of body and mind, that they were incapable of all resistance, and could never, upon the highest provocation, make us feel the effects of their resentment; the necessary consequence, I think, is that we should be bound by the laws of humanity to give gentle usage to these creatures, but should not, properly speaking, lie under any restraint of justice with regard to them... Our intercourse with them could not be called society, which supposes a degree of equality; but absolute command on the one side, and servile obedience on the other. Whatever we covet, they must instantly resign: Our permission is the only tenure, by which they hold their possessions: Our compassion and kindness the only check, by which they curb our lawless will: And as no inconvenience ever results from the exercise of a power, so firmly established in nature, the restraints of justice and property, being totally useless, would never have place in so unequal a confederacy.

This is plainly the situation of men, with regard to animals; and how far these may be said to possess reason, I leave it to others to determine. $^{17}$

Hume's version of the argument seems subject to the objection that if some group of people acquired sufficient power over the rest of us, they would cease to owe us

\footnotetext{
${ }^{17}$ HuME, Second Enquiry, pp. 190-91.
} 
justice. Suppose, for example, that a small coterie of people obtains joint control over the only weapon capable of blowing up certain major cities, and uses the threat of doing so to blackmail the rest of us into submission to their will. Since it is not in their interest to cooperate with us, by Hume's argument, they are not obligated to act justly towards the rest of us. Hume seems even to invite that objection, for he emphasizes that in order to have the kind of superior power that frees people from the obligation to concede rights to others, it is not enough that the members of one group to be stronger individually than the members of the other: they must also be sufficiently organized among themselves to maintain their force against the members of the weaker group. He says:

In many nations, the female sex are reduced to [...] slavery, and are rendered incapable of all property, in opposition to their lordly masters. But though the males, when united, have in all countries bodily force sufficient to maintain this severe tyranny, yet such are the insinuation, address, and charms of their fair companions, that women are commonly able to break the confederacy, and share with the other sex in all the rights and privileges of society. ${ }^{18}$

I will come back to this point later, because it brings out something important about our relationship to the other animals. Meanwhile, notice that Kant's argument may be seen as a version of the reciprocity argument, for he thinks it is only those

\footnotetext{
${ }^{18}$ HuME, Second Enquiry, p. 191.
} 
who stand in a certain kind of reciprocal relations with each other who can bind each other by law. ${ }^{19}$

If the reciprocity argument works, it captures something right about Kant's thought that the humane treatment of animals is something that we owe to ourselves. At least, insofar as the party to whom we owe a duty is the one who issues the law that gives us the duty, it is above all to ourselves that we owe it to treat the other animals humanely. ${ }^{20}$ But the trouble with this thought, at least as far as moral obligation is concerned, is that Kant thinks that the ultimate foundation of moral obligation in general is autonomy, the rational being's capacity for issuing laws to himself. Even on Kant's own account, we are bound by the moral law because we ourselves will that rational beings should be treated in certain ways. Morally speaking, you have the capacity to obligate me through your will only because it is the law of my own will that I should respect your choices. Suppose my earlier argument is correct, and we ourselves are committed to the principle that all beings for whom things can be good or bad, all beings with interests, should be treated as ends in themselves. Then even if animals cannot obligate us through their wills, they

\footnotetext{
${ }^{19}$ For a more detailed account of Kant's argument as a reciprocity argument, see KORSGAARD, Interacting with Animals. Notice, however, that Kant's version of the argument does not fall prey to the objection I have just made to Hume. In Kant's argument, it is everyone's freedom, not everyone's interest, which is at stake, and you cannot legitimately claim a right without upholding everyone else's freedom. So the coterie of powerful people would still owe the rest of us justice.

${ }^{20} \mathrm{Kant}$ also sometimes suggests that the reason we owe humane treatment to the other animals is that our treatment of other human beings is likely to be influenced by our treatment of the animals (MM 6:443; LE 27:459). Although it is now notorious that there is a connection between serious criminal behavior and animal abuse, the suggestion is a peculiar one for Kant to make. After all, if reason really did tell us the animal suffering does not matter in the way that human suffering does, why would we be tempted to treat humans in the same way we treat animals?
} 
can obligate us through their natures, as beings of that kind. For according to that argument, every act of our own will commits us the view that such beings are ends in themselves, and as such are laws to us.

\section{Why Animals Should Have Legal Rights}

The argument I have just given, however, applies only to the moral claims of animals. In the case of legal or political rights, there is again an additional problem, closely tied to the problems I mentioned at the beginning of the paper. According to Kant, the sense in which others can obligate us legally is different from the sense in which they can obligate us morally (MM 6:218-221). The sense in which others can obligate us legally does not "go through" our own autonomy in the way I described above. Rather, the sense in which people can obligate us legally is that they may legitimately use coercion to enforce their rights. Coercion, as I mentioned at the beginning, may legitimately be used only for the sake of protecting freedom, a kind of freedom that the other animals, not being rational, apparently do not have. If the point of animal rights is simply to protect their interests, not to protect their freedom, then there seems to be no room for animal rights in a Kantian account.

But a closer examination of Kant's own argument again reveals grounds for questioning this conclusion. Earlier we saw how Kant grounds our claim to be ends in ourselves by showing that it is a presupposition of rational choice - a claim that is in a sense built into every act of rational choice. When I pursue the things that are good for me as if they were good absolutely, I commit myself to the principle that 
beings for whom things can be good or bad are ends in themselves. In much the same way, Kant tries to show that a commitment to enforceable rights for everyone, and therefore to a political state with a legal system, is built into every claim of right that I make for myself.

Here is how the argument goes. A legal or political right, as Kant understands it, is an authorization to use coercion. To say that you have a legal right to some piece of property is to say that if someone attempts to use it without your permission, you may legitimately use force to prevent him from doing so. But coercion is only legitimate when it is used in the service of freedom. Why then may we use it to defend our property? Like others in the social contract tradition, Kant envisions a state of nature in which people lay claim to parts of the commons for their own private use. ${ }^{21}$ If it were not possible to claim objects as our own, Kant argues, we could not effectively use them when they were not in our physical possession. Or even if we could, our use of them would be subject to the will of others in a way that is inconsistent with our freedom. I cannot effectively grow wheat on my land if you might move in at any time and grow beans there, and I cannot do so freely if the only way I can do it is in effect to get your permission. In order to make free use of the land I must be able to claim a right to it. A piece of property is a kind of extension of one's freedom. To deny the possibility of claiming objects in this way would amount to placing an arbitrary restriction on freedom (MM 6:246). Therefore we must

\footnotetext{
${ }^{21}$ I will come back to the role of the idea of the commons in these arguments below.
} 
concede that such claims - claims of enforceable right - are possible. Kant calls this "the postulate of practical reason with regard to rights" (MM 6:246).

So I can make it a law for you that you cannot use a certain piece of land without my permission. But I cannot do this unilaterally, since I am not your master. Rather, as we saw before, my claims of right must be made in the name of laws that have authority for us both, laws that we make together. In Rousseau's language, my claim must be in made in the name of the General Will in order for it to have the force of law. Rights, Kant argues, are only "provisional" in the state of nature, since they cannot be fully realized until everyone's rights are protected by actual, coercively enforced laws, by a state with a legal system (MM 6:255-257). This is why it is a duty for us to leave the state of nature and live in political society. Kant calls that the "Postulate of Public Right" (MM 6:307). I am going to call Kant's two postulates taken together "the Presupposition of Enforceable Rights."

Since we must survive, we have to claim pieces of property for our own use, just as since we must act, we have to make rational choices to pursue certain ends. If the rational pursuit of my ends involves the presupposition that I have the right to use certain objects in pursuit of my ends, and that in turn involves the presupposition that everyone's rights should be upheld and enforced, then the Presupposition of Enforceable Rights is built into the rational pursuit of my ends. This exactly parallels the way that the presupposition that beings with interests should be treated as ends in themselves is built into the rational pursuit of my ends. 
But who exactly is the "everyone" whose rights should be enforced? It is only rational beings who must lay claim to rights, and only rational beings who hold one another to the presuppositions of those claims, just as it is only rational beings who choose to pursue their ends, and are rationally bound by the presuppositions of their choices. Before we saw that it does not obviously follow that the presupposition behind rational choice is that rational beings are ends in themselves, and in fact when we looked more closely at the context in which the presupposition operates at the most basic level - namely, in my decision to pursue something simply because I think it will be good for me - it does not seem to follow at all. Rather what follows is that I am committed to the idea that if I am the sort of being for whom things can be good or bad, a being with interests, then I should be treated as an end in itself. In this case too we need to look more closely at the context in which the presupposition of enforceable rights first operates, which is the context of original acquisition.

But here we run into a problem. Although the problem is a general problem about ownership rights, it will be useful to pose it first as a problem about our rights (that is, the rights of human beings) to own animals. This will enable us to ask a question which we should be asking anyway, which is this: even if it were not the case that the other animals could have rights against us, how exactly is it suppose to follow that we have rights over them? Putting the problem more generally, why is it supposed to follow from the fact that we need to claim objects as our own in order to use them effectively and freely, that we can claim anything we find in the world, even an animate being with a life of its own, that is not already claimed? 
In the traditional doctrines of rights developed in the 17th and 18th century, especially in the theories of Locke and Kant, it is perfectly clear why this is supposed to follow. It follows from two theses. The first is a view originally derived from Genesis that found its way into these theories. That is the view that God gave the world and everything in it to humanity to hold in common. ${ }^{22}$ The second is a picture of what a right in general is, a picture associated with the reciprocity argument. To claim that I have a right is to make a relational claim; and the relation is not between me and the object to which I have a right - it is between me and other people. When we put these two claims together, we get a certain picture of what the general problem of individual rights is, a picture which is explicit in and familiar to us from the work of Locke, but also implicitly at work in the Kantian views we have just been reviewing. The problem of individual rights is conceived as a problem about what gives someone a right to take something out of the commons; or, to put it more carefully, about how I can take something out of the commons in a way that is justifiable to everyone else. Both Kant's insistence that rights must be established in accordance with the General Will and Locke's famous proviso - that the one who claims a right must leave as much and as good for others - are based in part on this picture. ${ }^{23}$ Indeed Kant insists on the essential role of this assumption in his theory. The "real definition" of a right to a thing, Kant says:

\footnotetext{
${ }^{22}$ Actually, in Genesis 1:29-30, God gives the plants to human beings, and then in Genesis 9:3, God gives everything living and moving to human beings.

${ }^{23}$ Locke, Second Treatise of Government, Chapter V, paragraph 33, p. 21.
} 
$[\ldots]$ is a right to the private use of a thing of which I am in (original or instituted) possession in common with all others. For this possession in common is the only condition under which it is possible for me to exclude every other possessor from the private use of a thing $[\ldots]$, since, unless such a possession in common is assumed, it is inconceivable how I, who am not in possession of the thing, could still be wronged by others who are in possession of it and are using it (MM $6: 261)$.

Kant's assumption is slightly different from Locke's, because he distinguishes possession from ownership properly speaking, and it is common possession that he posits. When something is in my physical possession, anyone (that is, anyone who is not its rightful owner) who tries to use it without my permission wrongs me, because he has to use force to get it away from me. This much follows simply from my innate right to freedom, which Kant understands to include control over my own body. When I own something, someone who uses it without my permission wrongs me even when I am not in physical possession of it. The assumption of common possession seems less extravagant, for in a way it is simply the claim that no one has a prior right that would make it legitimate for them to exclude us from using the earth and its resources, and therefore to exclude us from dividing it up into property. Either way, however, the role of the assumption is to answer an obvious question: How could our agreement to divide the world up in a certain way have any authority, if we had no right to it in the first place? 
Despite its religious formulation, the claim that God gave us the world in common captures an idea that goes right to the heart of the moral outlook, and can be formulated in secular terms. It is the idea that others have just as good a claim on the resources of the world as we do, and that it behooves us to limit our own claims with that in mind. But the idea of the world as owned or possessed in common by humanity also represents the world, and everything in it, including the animals, as one big piece of property. That Kant was prepared to represent the world this way is important, because it shows that Kant had no principled reason for regarding animals as possible property. He simply assumed that that is what they are.

At the beginning of this paper, I said that it is inconsistent with Kant's methodology simply to accept metaphysical claims about value. Claims about value, like any claims that go beyond the realm of empirical experience, must be established in a certain way. They must be shown to be necessary presuppositions of rational activity. The claim that world is given to us in common is certainly such a claim, not scientifically provable. Is it just a religious or metaphysical claim that really should have no place in Kant's philosophy? Or could we regard it instead as a presupposition of rational activity? In fact, in its modified form as the presupposition of common possession, Kant explicitly claims that we can. He says:

All human beings are originally (i.e. prior to any act of choice that establishes a right) in a possession of land that is in conformity with right, that is, they have a right to be wherever nature or chance (apart from their will) has placed them. This kind of possession $[\ldots]$ is a 
possession in common because the spherical surface of the earth unites all places on its surface [...]. The possession by all human beings on the earth which precedes any act of theirs that would establish rights $[\ldots]$ is an original possession in common [...], the concept of which is not empirical [...]. Original possession is, rather, a practical rational concept which contains a priori the principle in accordance with which alone people can use a place on the earth in accordance with principles of right. (MM 6:262)

Before there are any other rights, before we start dividing up the world for our purposes, each of us has a right to be where he or she is, wherever "nature or chance" has placed us. ${ }^{24}$ The right to be where you are is an aspect of your right to control over your own body, since it means that in the absence of prior claims, no one has a right to force you to move on. Since a right to the earth, for Kant, goes with a right to use its resources for your support, that means that each of us has a right to take what he or she needs in order to live.

In other words, we are thrown into the world, and having no choice but to use the land and its resources in order to support and maintain ourselves, we have no choice but to assume at least that we are doing nothing wrong in doing that. But we are not the only creatures thus thrown into the world, with no choice but to use the earth and its resources in order to live. If this is the basis of the presumption of

\footnotetext{
${ }^{24}$ Readers of DiCKENS Bleak House may remember the poor boy Jo, who does not have a right to be where he is - he is always being told by the constable to "move on" - and consequently has no rights at all.
} 
common possession or ownership, why not assume that the earth and its resources are possessed in common by all of the animals? ${ }^{25}$

Again, it is true that rational beings are the only animals who must conceive of their situation in these normative and moral terms, and therefore the only beings who must presuppose that we have a right to use the earth for our maintenance. But it does not follow that what we have to presuppose is that rational beings, and rational beings alone, have that right. In the absence of a prior religious commitment, it is arbitrary to make any assumption except the assumption that the world belongs in common to all of the creatures who depend on its resources. Only some sort of metaphysical insight into a special relationship that human beings stand in to the universe could justify the assumption that it belongs only to us, and that is exactly the sort of metaphysical insight that Kant denies that we have. To the extent that the kind of "freedom" that is at stake in rights is simply the freedom to use your own body to carve out some sort of a decent life in the world where you find yourself, then the "freedom" of the other animals is the sort of thing that could be protected by rights after all. ${ }^{26}$

\footnotetext{
${ }^{25}$ As I mentioned in note 20, in the Genesis account the plants of the world are given to the animals before the animals are given to human beings

${ }^{26}$ Of course I am not suggesting that the correct way to protect the lives of animals is arrange for them to them own property. Nor is there any hope of dividing up the world in a way that leaves "enough and as good" for every animate creatures when some of them must live by preying on others. But in the case of wildlife, we might think some duties of habitat preservation do follow, and domestic animals certainly have a right not to be starved. The most suggestive thought here is that if animals do have this kind of freedom, we do not have a right to their bodies: those are not ours to do with as we please. But the details of what is required by the arguments of this paper, of which rights animals should have, remain to be worked out.
} 
Of course, despite what Kant plausibly says about its necessity, we could drop the presupposition of common possession or common ownership altogether. But if we drop the presupposition altogether, we must also drop the version of it that comes down to us from Genesis. In that case, the world was not given to human beings in common, because it was not given to anyone. That means that what human beings have over the other animals is not, in general, a form of rightful ownership. It is simply power.

Now recall that the starting point for Kant's theory of why we must conceive ourselves to have rights is the wrongness of the unilateral domination of some individuals by others. It is the wrongness, to put it more colloquially, of the view that might makes right. The reason why the political state and its legal apparatus exists at all, according to Kant, is not that fighting over everything all the time is inconvenient, or that life in the state of nature is, as Hobbes famously reminded us, nasty, brutish, and short. It is the urgency of standing in relations with others that we can regard as rightful that prompts us to establish a system of enforceable legal rights.

But human beings, collectively speaking, do stand in relations of unilateral domination over the other animals. I am not talking now about a relation in which we as a species stand to them as species. I am talking about a relation in which human beings stand as an organized body to individual animals who are not part of 
any such body. To us the other animals are a subject population, rendered almost completely at our mercy by our intelligence, power, and organizational skills. ${ }^{27}$

In fact, when Hume describes the relations in which people stand to animals, he is describing exactly the sort of unilateral domination of some beings by others the wrongness of which is the starting point of Kant's political philosophy. And when he talks about the relations in which men stand to women, Hume, with his characteristic political realism, brings out the important thing that makes such unilateral domination possible. It is that the dominant group be able to organize itself as a group, while members of the dominated group can only resist as individuals, if indeed they can resist at all. This is an essential feature of the relationship in which human beings stand to the other animals. And the way that we unite and organize ourselves is by constructing our legal systems.

Earlier I pointed out that the problem Kant has in mind when he constructs his account of rights does not concern the probability of bad behavior. He thinks it is wrong in itself for one person to be completely subject to another person's will. Unilateral domination is a moral wrong whether it is abused or not. But I did not say that unilateral domination is not the source of bad behavior - and notoriously, it is. You need only look at what goes on inside of our factory farms and experimental laboratories to see what the possibility of such domination - the ability to do whatever we like with another animal - can lead to. So long as there are profits to be

\footnotetext{
${ }^{27}$ Here it is important to remember that I am talking about how human beings stand collectively to animals individually. As species, many of them are also subject to our domination - it is up to us whether many species will survive. But that certainly is not true of all of them. Collectively speaking, the mosquitoes may defeat us yet.
} 
made, and the tantalizing prospect of expanding the human lifespan by experiments on the other animals, there will be people who will do anything, no matter how cruel it is, to a captive animal. And what makes this possible is the legal status of animals as property. It is not plausible to hope that the human race will someday have a collective humanitarian conversion and bring all such practices to an end, without any help from the law. But even if it were, the argument would stand. No matter how well-intentioned we are, we can only be rightly related to our fellow creatures if we offer them some legal protections.

If we must presuppose that the world and all that is in is possessed by us common, so that we may use it rightfully, then we should presuppose that it is possessed by all of its creatures on the same ground. The other animals are not part of what we own, to use as we please, but rather are among those to whom the world and its resources belong. If we reject the presupposition of common possession or ownership, then we cannot pretend that the way we treat the other animals is anything but an exercise of arbitrary power, the power of the organized over the weak. In that case, I suppose it is up to us how we treat them - but the moral argument still holds. The other animals are, just as much as we are, beings with interests, beings for whom things can be good or bad, and as such they are ends in themselves. Either way, the only way we can be rightly related to them is to grant them some rights. 


\section{Conclusion}

Despite his own views about animals and their claims, Kant's philosophy captures something about our own existential situation that proclaims our fellowship with the other animals. It is the central insight of Kant's philosophy that the laws of reason are our laws, human laws, and that we cannot know whether the world as it is in itself conforms to them or not. The fact that we are rational does not represent a privileged relationship in which we stand to the universe. Kant also believed that morality is a kind of substitute for metaphysics, giving us grounds to hope for what we cannot know through any metaphysical insight - that the world can, through our efforts, be made into a place that meets our standards, that is rational and good. ${ }^{28}$ That means we share a fate with the other animals, for like them, we are thrown into a world that gives no guarantees and are faced with the task of trying to make a home here. It is a presupposition of our own rational agency and of our moral and legal systems that the fate of every such creature, every creature for whom life in this world can be good or bad, is something that matters. That is why we should concede the moral claims of the other animals, and protect those claims as a matter of legal right. ${ }^{29}$

\footnotetext{
${ }^{28}$ See note 10.

${ }^{29}$ An earlier version of many of the arguments in this paper was discussed in a workshop on my work on ethics and animals at New York University in September 2011 and by an ethics reading group at Stanford in October 2011. I would like to thank Charlotte Brown, Tom Doherty, Lori Gruen, Beatrice Longuenesse, Peter Singer, and Jeremy Waldron for comments.
} 


\section{Bibliography}

Dickens CharLes, Bleak House (New York: W. W. Norton \& Co. Inc, 1977. (cit. DICKENS Bleak House).

HobBes THOMAS, Leviathan. Ed. CURLEY EDWIN. Indianapolis: Hackett Publishing Company, 1994. (cit. HOBBES, Leviathan).

HUME DAVID, Enquiry Concerning the Principles of Morals. In Enquiries Concerning Human Understanding and Concerning the Principles of Morals. 3rd edition. Ed. SElBY-BIGGE L.A. and NidDiTCH P.H. Oxford: Clarendon Press, 1975. (cit. HUME, Second Enquiry).

KANT IMMANUel, Critique of Judgment. Trans. Pluhar Werner S. Indianapolis: Hackett Publishing Company, 1987.

KANT IMMANUEL, Critique of Practical Reason. Trans. and ed. GREGOR MARY. Cambridge Texts in the History of Philosophy series. Cambridge: Cambridge University Press, 1997.

KANT IMMANUEL, Groundwork of the Metaphysics of Morals. Trans. and ed. GREGOR MARY. Cambridge Texts in the History of Philosophy series. Cambridge: Cambridge University Press, 1998.

KANT IMMANUEL, Kants Gesammelte Schriften. Ed. Royal Prussian (later German) Academy of Sciences. Berlin: George Reimer, later Walter de Gruyter \& Co., 1900--.

Kant Immanuel, Lectures on Ethics. Trans. Heath Peter, ed. Heath Peter and SCHNEEWIND J. B. New York: Cambridge University Press, 1997. These "lectures" are actually students' notes from Kant's ethics courses.

KANT IMMANUEL, The Metaphysics of Morals. Trans. and ed. GREGOR MARY. Cambridge Texts in the History of Philosophy series. Cambridge: Cambridge University Press, 1996.

KANT IMMANUEL, "Conjectures on the Beginnings of Human History." In Kant's Political Writings. 2nd ed. Trans. NISBET H. B. and ed. REIsS HANS. Cambridge: Cambridge University Press, 1991.

KORSGAARD CHRISTINE M., "Fellow Creatures: Kantian Ethics and Our Duties to Animals" in The Tanner Lectures on Human Values; Volume 25 (2005). Ed. Peterson Grethe B. Salt Lake City: University of Utah Press, 2005. (cit. KORSGAARD, Fellow Creatures). 
(KoRSGAARD CHRISTINE M., "Interacting with Animals: A Kantian Account."

In The Oxford Handbook of Animal Ethics. Ed. BEAUCHAMP TOM and FREY R. G. Oxford University Press, 2011. (cit. KORSGAARD, Interacting with Animals).

KORSGAARD CHRISTINE M., "Just Like All the Other Animals of the Earth" Harvard Divinity Bulletin, Summer 2008. (cit. KORSGAARD, Just Like All the Other Animals).

KORSGAARD CHRISTINE M., "Kant's Formula of Humanity." In KORSGAARD Christine M., Creating the Kingdom of Ends. New York: Cambridge University Press, 1996. (cit. KORSGAARD, Formula of Humanity).

KORSGAARD CHRISTINE M., "The Origin of The Good and Our Animal Nature." In Problems of Goodness: New Essays on Metaethics. Ed. REICHARDT BASTIAN. forthcoming from Bernstein Verlag. (cit. KORSGAARD, Origin of the Good).

KORSGAARD CHristine M., Self-Constitution: Agency, Identity, and Integrity. Oxford: Oxford University Press, 2009. (cit. KORSGAARD, Self-Constitution).

KORSGAARD CHRISTINE M., The Sources of Normativity. Cambridge: Cambridge University Press, 1996. (cit. KORSGAARD, Sources of Normativity).

LOCKE JOHN, Second Treatise of Government. Ed. MACPHERSON C. B. Indianapolis: Hackett Publishing Company, 1980. (cit. LOCKE, Second Treatise).

RAWLS JOHN, $A$ Theory of Justice. Cambridge, MA: Harvard University Press, 2nd edition 1999. (cit. RAWLS, Theory of Justice).

Rousseau Jean-Jaceues, On the Social Contract. Ed. CREss Donald A. Hackett Publishing Company: Indianapolis, 1987. (cit. ROUSSEAU, Social Contract). 